\title{
Tempering of Low-Temperature Bainite
}

\author{
MATHEW J. PEET, SUDARSANAM SURESH BABU, MIKE K. MILLER, \\ and H.K.D.H. BHADESHIA
}

\begin{abstract}
Electron microscopy, X-ray diffraction, and atom probe tomography have been used to identify the changes which occur during the tempering of a carbide-free bainitic steel transformed at $473 \mathrm{~K}\left(200{ }^{\circ} \mathrm{C}\right)$. Partitioning of solute between ferrite and thin-films of retained austenite was observed on tempering at $673 \mathrm{~K}\left(400{ }^{\circ} \mathrm{C}\right)$ for 30 minutes. After tempering at $673 \mathrm{~K}\left(400{ }^{\circ} \mathrm{C}\right)$ and $773 \mathrm{~K}\left(500{ }^{\circ} \mathrm{C}\right)$ for 30 minutes, cementite was observed in the form of nanometre scale precipitates. Proximity histograms showed that the partitioning of solutes other than silicon from the cementite was slight at $673 \mathrm{~K}\left(400{ }^{\circ} \mathrm{C}\right)$ and more obvious at $773 \mathrm{~K}\left(500{ }^{\circ} \mathrm{C}\right)$. In both cases, the nanometre scale carbides are greatly depleted in silicon.
\end{abstract}

DOI: $10.1007 / \mathrm{s} 11661-017-4086-\mathrm{x}$

(C) The Author(s) 2017. This article is an open access publication

\section{INTRODUCTION}

PROCEDURES for the design of bainitic nanostructured steels in bulk form have been established. ${ }^{[1-4]}$ Modeling the effects of composition on transformation kinetics enables tailored alloying to allow isothermal transformation at suppressed temperatures, while silicon additions prevent the precipitation of coarse carbides during the bainite transformation ${ }^{[1,2]}$ Isothermal transformation circa $473 \mathrm{~K}\left(200{ }^{\circ} \mathrm{C}\right)$ then results in a structure of fine bainitic ferrite plates (width 20 to $40 \mathrm{~nm}$ ) separated by thin-films of austenite. ${ }^{[1,2,5]}$ The fine scale of the structure is a consequence of the displacive transformation mechanism ${ }^{[6]}$ and contributes significantly to the strength and hardness, ${ }^{[7]}$ while retained austenite contributes to the toughness and elongation. ${ }^{[8]}$

Carbide precipitation in a nanobainitic steel has been observed using atom probe tomography to be associated with the formation of carbon-depleted austenite after isothermal transformation at $473 \mathrm{~K}\left(200{ }^{\circ} \mathrm{C}\right)$ in composition Fe-0.79C-1.5Si-1.98Mn-0.24Mo-1.06Al$1.59 \mathrm{Co} \mathrm{wt} \mathrm{pct.}{ }^{[9]}$ Therefore, the tempering behavior of these alloys is of interest both to understand the thermal stability and the scope for tailoring the mechanical properties. Softening may also be necessary to allow thermo-mechanical processing. ${ }^{[10,11]}$ Previous work has shown that these steels are relatively resilient to tempering. ${ }^{[1,8,12]}$ The fine plate size provides the dominant strength contribution, so high hardness is maintained until coarsening of the bainitic ferrite occurs. ${ }^{[12,13]}$

MATHEW J. PEET and H.K.D.H. BHADESHIA are with the Department of Materials Science and Metallurgy, University of Cambridge, 27 Charles Babbage Road, Cambridge CB3 0FS, UK. Contact e-mail: mathew@mathewpeet.org SUDARSANAM SURESH BABU is with the University of Tennessee, Knoxville, TN 37916, and also with the Oak Ridge National Laboratory, Oak Ridge, TN 37831. MIKE K. MILLER is with the Oak Ridge National Laboratory.

Manuscript submitted September 24, 2016.

Article published online April 10, 2017
Development of alloys with increased temperature stability is in progress; this will rely on further suppressing carbide precipitation to increase the stability of the nanostructure. ${ }^{[14]}$ So there are a several strong motivations to characterize the tempering behavior of these nanostructured steels.

Previous work has found that nanostructured bainitic steels exhibit excellent tempering resistance, retaining much of the hardness to temperatures above $723 \mathrm{~K}$ to $773 \mathrm{~K}\left(450{ }^{\circ} \mathrm{C}\right.$ to $\left.500{ }^{\circ} \mathrm{C}\right)$ for 1 hour. In the current study, the structures after 30 minutes tempering treatments at $673 \mathrm{~K}\left(400{ }^{\circ} \mathrm{C}\right)$ and $773 \mathrm{~K}\left(500{ }^{\circ} \mathrm{C}\right)$ on the alloy with composition Fe-0.75C-1.63Si-1.95Mn-1.48Cr-0.28Mo-0.1V wt pct (Table I) designated A2 transformed at $473 \mathrm{~K}\left(200{ }^{\circ} \mathrm{C}\right)$ were characterized using atom probe tomography. Both heat treatments are in the range of tempering temperatures where retained austenite decomposes as determined using ex situ X-ray diffraction.

Tempering heat treatments are commonly applied to quenched martensitic steels, at temperatures below those for the formation of austenite, to reduce hardness and optimize combinations of strength and toughness. Several stages of tempering are classically identified, although often two stages occur simultaneously. ${ }^{[15-18]}$ The stages correspond to formation of $\epsilon$-carbide from supersaturated martensite between $323 \mathrm{~K}$ and $523 \mathrm{~K}$ $\left(50{ }^{\circ} \mathrm{C}\right.$ and $250{ }^{\circ} \mathrm{C}$ ), transformation of retained austenite to $\epsilon$-carbide and ferrite from $473 \mathrm{~K}$ to $573 \mathrm{~K}\left(200{ }^{\circ} \mathrm{C}\right.$ to $300{ }^{\circ} \mathrm{C}$ ), formation of cementite from $\epsilon$-carbide and from martensite in the range $473 \mathrm{~K}$ to $623 \mathrm{~K}\left(200{ }^{\circ} \mathrm{C}\right.$ to $350{ }^{\circ} \mathrm{C}$ ), then finally cementite coarsening and ferrite recrystallization above $623 \mathrm{~K}\left(350{ }^{\circ} \mathrm{C}\right)$.

Atom probe studies have previously elucidated many aspects of the tempering process. Partitioning during cementite precipitation from supersaturated martensite has been studied using an atom probe by Thompson and Miller ${ }^{[19]}$ in Fe- $(0.15,0.4) \mathrm{C}-2.25 \mathrm{Cr}-1 \mathrm{Mo}$ wt pct steels, observing that chromium, manganese, or molybdenum did not partition after 40 hours at $623 \mathrm{~K}\left(350^{\circ} \mathrm{C}\right)$, indicating a paraequilibrium transformation to cementite. After 187 hours at $723 \mathrm{~K}\left(450^{\circ} \mathrm{C}\right)$ chromium, 
Table I. Chemical Compositions of Alloys Studied/Weight Percent

\begin{tabular}{lccccccccccc}
\hline Alloy & $\mathrm{C}$ & $\mathrm{Si}$ & $\mathrm{Mn}$ & $\mathrm{Ni}$ & $\mathrm{Cr}$ & $\mathrm{Mo}$ & $\mathrm{V}$ & $\mathrm{Al}$ & $\mathrm{Co}$ & $\mathrm{P}$ & $\mathrm{S}$ \\
\hline $\mathrm{A}^{[1]}$ & 0.79 & 1.59 & 1.94 & 0.02 & 1.33 & 0.3 & 0.11 & - & - & - \\
$\mathrm{A}^{[12,31]}$ & 0.75 & 1.63 & 1.95 & - & 1.48 & 0.28 & 0.10 & $<0.01$ & - & 0.003 \\
$\mathrm{~B}^{[48,49]}$ & 0.98 & 1.46 & 1.89 & - & 1.26 & 0.26 & 0.09 & - & - & $<0.003$ \\
\hline
\end{tabular}

manganese, and molybdenum were enriched in the cementite, with greater enrichment in the outer regions of cementite which shared an interface with ferrite. Chromium was observed to partition more quickly than manganese or molybdenum. Silicon had partitioned from cementite into the matrix. From these observations, it was concluded that the diffusion of solutes in the matrix was the rate limiting step in the early stages of enrichment.

Redistribution of carbon in the early stages of tempering has been studied by Miller et al. ${ }^{[2-22]}$ for iron-carbon and iron-nickel-carbon alloys. It was observed that carbon segregates to lattice defects such as coherent twin boundaries, lath boundaries, and high-angle grain boundaries.

The tempering resistance effect due to silicon in martensitic steels was first reported by Jack $^{[16]}$ and Owen. ${ }^{[23]}$ Early atom probe studies by Barnard et al. ${ }^{[24]}$ and Chang and Smith ${ }^{\text {25] }}$ showed the rejection of silicon from the growing cementite plates. The low solubility of silicon in cementite inhibits growth in later stages, with kinetics controlled by diffusion of silicon rather than carbon. Pereloma et al. also observed partitioning of silicon (and manganese) from cementite in upper-bainite. ${ }^{[26]}$ According to theory, the major effect of silicon may well be on nucleation of new cementite plates; Ghosh and Olson, ${ }^{[27]}$ Bhadeshia et al., ${ }^{[28]}$ and Kozeschnik and Bhadeshia ${ }^{[29]}$ have all performed calculations showing that nucleation can be dramatically reduced or prevented by silicon, due to any potential cementite particle being forced to initially accept silicon at the paraequilibrium level.

As pointed out by Caballero et al., ${ }^{[30]}$ although precipitation of cementite in these structures is thought to occur in a manner similar to the tempering of martensitic steels, there have been few previous studies on the redistribution of elements during the tempering of carbide-free bainites. The goal of this work was to further characterize the substitutional and interstitial element redistribution between bainitic ferrite, austenite, and carbides during tempering.

\section{EXPERIMENTAL PROCEDURES}

Alloys were produced as $25 \mathrm{~kg}$ melts, rolled into $40-\mathrm{mm}$ plate and homogenized for 48 hours at $1473 \mathrm{~K}$ $\left(1200{ }^{\circ} \mathrm{C}\right)$. Samples for examination by atom probe were prepared from alloy A2 transformed at $473 \mathrm{~K}\left(200^{\circ} \mathrm{C}\right)$ and subsequently tempered for 30 minutes at $673 \mathrm{~K}$ $\left(400{ }^{\circ} \mathrm{C}\right)$ and $773 \mathrm{~K}\left(500^{\circ} \mathrm{C}\right)$. Samples from an alternate melt of similar composition (alloy A1) were similarly prepared and tempered for various times - this material was used for inspection by X-ray diffraction and electron microscopy. Further details and an earlier analysis of the results were previously reported. ${ }^{[31]}$

Rods of 3-mm diameter were produced by electrical-discharge machining from alloy A1, sealed in quartz tubes back-filled with argon, and homogenized for 2 days at $1473 \mathrm{~K}\left(1200{ }^{\circ} \mathrm{C}\right)$. Samples were removed and re-sealed in fresh quartz tubes for austenitization at $1273 \mathrm{~K}\left(1000{ }^{\circ} \mathrm{C}\right)$ for 15 minutes. To aid fast cooling, the tubes were shattered before transfer of the rod into a second furnace where the material was transformed at $473 \mathrm{~K}\left(200^{\circ} \mathrm{C}\right)$ held in an alumina boat.

Hardness tests were performed on 3 to $4 \mathrm{~mm}$ lengths of the rod, mounted in Bakelite, and three hardness indents made with a $30 \mathrm{~kg}$ load using a Vickers diamond pyramidal indenter.

After transformation the rods were sliced to $\sim 250 \mu \mathrm{m}$-thick disks with a silicon carbide cutting wheel, and ground to 40 to $100 \mu \mathrm{m}$ using 1200 grit silicon carbide papers. These were thinned to produce samples for transmission electron microscopy by use of a twin jet polishing machine with a solution of 80 pct ethanol, 15 pct glycerol, and 5 pct perchloric acid. Polishing voltages were varied between 20 and $40 \mathrm{~V}$.

Prior to electropolishing samples were analyzed by $\mathrm{X}$-ray diffraction to measure the ferrite and austenite volume fractions and lattice-parameters. The 3-mm disks were attached by vacuum grease in a $3 \times 3$ grid to a silicon wafer (which was a single crystal aligned to not produce any diffraction peaks), and placed in a Philips PW1730 X-ray diffractometer. Unfiltered $\mathrm{Cu} \mathrm{K} \alpha$ radiation was generated from an X-ray tube at $45 \mathrm{kV}$ and $45 \mathrm{~mA}$ accelerating voltage and current.

Lattice parameters and the volume fraction of austenite were determined by the Rietveld method using Philips HighScore Plus software. The carbon content of ferrite and austenite were then calculated using relations proposed by Dyson and Holmes. ${ }^{[32,33]}$

For characterization by atom probe tomography, tip samples were prepared by two-stage electropolishing using standard methods as described by Miller. ${ }^{[34]}$ The studies were performed using both the Kindbrisk (now CAMECA Instruments Inc.) energy-compensated optical position-sensitive atom probe (ECOPOSAP) and the Imago Scientific instruments (also now CAMECA) local electrode atom probe LEAP 2017. ECOPOSAP and LEAP experiments were performed in voltage mode with a specimen temperature of $60 \mathrm{~K}$, and pulse fraction of 0.2 of the standing voltage. The pulse repetition rates were $1.5 \mathrm{kHz}$ in ECOPOSAP and $200 \mathrm{kHz}$ in LEAP, the average ion collection rate in LEAP was 2 pet.

In the analysis of data isoconcentration surfaces and proximity histograms were derived for a voxel of $2^{3} \mathrm{~nm}^{3}$ 
and a delocalization of $4 \mathrm{~nm}$ using CAMECA's IVAS software, which implements methods developed by Hellman et al. ${ }^{[35-37]}$ Proximity histograms were represented as distance versus carbon at. pct, or the ratio of the number of each elements atoms against the number of iron atoms. This ratio will be preserved unless substitutional diffusion takes place.

\section{RESULTS AND DISCUSSION}

The tempering resistance of low-temperature bainitic steel, as measured by the change in hardness, is demonstrated by the result of holding for 1 hour at increasing temperatures (Figure 1). Measurement of phase fraction by X-ray diffraction reveals that austenite decomposition occurs before any significant decrease in hardness, which mostly decreases above $773 \mathrm{~K}\left(500{ }^{\circ} \mathrm{C}\right)$. An initial analysis of $\mathrm{X}$-ray and TEM results is also available in Reference 13. Samples tempered for $30 \mathrm{~min}$ utes at $673 \mathrm{~K}\left(400{ }^{\circ} \mathrm{C}\right)$ and $773 \mathrm{~K}\left(500^{\circ} \mathrm{C}\right)$ were selected for investigation by atom probe tomography.

As shown in Figure 2 after tempering at $673 \mathrm{~K}$ $\left(400{ }^{\circ} \mathrm{C}\right.$ ) for 30 minutes, the microstructure of fine bainite plates separated by thin-film austenite remains. X-ray diffraction (Figure 1; Table II) demonstrates that austenite is still present after tempering for 1 hour at $723 \mathrm{~K}\left(450{ }^{\circ} \mathrm{C}\right)$. Dark field electron microscopy and electron diffraction, Figure 3, confirms the crystal structure of the thin-films as austenite. Figure 4 shows the distribution of cementite particles after tempering at $773 \mathrm{~K}\left(500{ }^{\circ} \mathrm{C}\right)$ for 30 minutes, although this does not eliminate the possibility of other carbide particles being present in smaller amounts.

In the as-transformed condition, the bainitic ferrite has a large supersaturation of carbon some $1.1 \pm 0.7$ at. pct, $(\sim 0.25 \mathrm{wt}$ pct $)$, with respect to equilibrium with austenite or cementite. The austenite contains $8 \pm 1.6$ at. pct $(\sim 2 \mathrm{wt}$ pct) which is double that expected from cessation at the locus of the thermodynamic $T_{0}$ (4.1 at. pct). ${ }^{[31]}$ X-ray diffraction measurements show that the large amount of carbon retained in the ferrite is correlated to non-uniform lattice strain and that both decrease on tempering. ${ }^{[12]}$ One

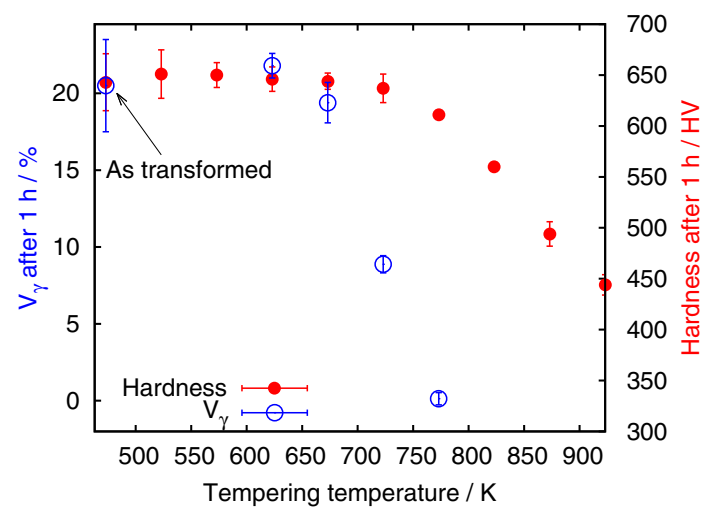

Fig. 1-Changes in alloy hardness and volume fraction of austenite due to tempering $1 \mathrm{~h}$ in alloy $\mathrm{A} 1$. explanation is that much of the carbon is present at dislocations, as observed by atom probe tomography. ${ }^{[38]}$ More recently, the possibility has been investigated using density functional calculations that tetragonality of the bainitic ferrite may also act to stabilize the high carbon content. ${ }^{[39]}$ This is the topic of continuing investigations using synchrotron radiation ${ }^{[40,41]}$ and neutron diffraction.

Alloy A2 transformed at $473 \mathrm{~K}\left(200{ }^{\circ} \mathrm{C}\right)$ was tempered at $673 \mathrm{~K}\left(400{ }^{\circ} \mathrm{C}\right)$ for 30 minutes leaving 17.5 vol. pct of austenite (Table II). An austenite thin-film was observed in the tomographic volume, Figure 5, and proximity histograms as shown in Figure 6 provide a composition profile across the ferrite-austenite interface. The carbon variation can be attributed to partitioning with austenite containing about 6 at. pct and ferrite $\sim 1$ at. pct, lower than observed immediately after transformation. For ferrite volumes in Figure 5, the carbon was seen to vary between 0.5 and 1.5 at. pct with an average of $1.01 \pm 0.03$ at. pet $(0.25 \mathrm{wt}$ pct $)$. Consequently isosurfaces for 2 or 5 pct carbon have been arbitrarily chosen to indicate the positions of carbide particles in projections of tomographic data.

Previous analysis of the data using simple composition profiles across the interfaces suggested that substitutional solutes did not partition between the phases. ${ }^{[13]}$ In contrast, the better resolution of the interface in the proximity histograms used here shows that manganese concentration has started to decrease in the ferrite nearest to the interface with austenite, and increase in the austenite, Figure 6. Such partitioning of substitutional elements is possible as a result of tempering. For comparison, at $673 \mathrm{~K}\left(400{ }^{\circ} \mathrm{C}\right)$ for 30 minutes, the random walk diffusion distance for manganese in iron is around $0.5 \mathrm{~nm}$.

The ferrite and austenite carbon contents are similar to those determined indirectly using the X-ray diffraction, Table II $\quad(0.27 \pm 0.06 \mathrm{wt}$ pct in ferrite, $1.26 \pm 0.06 \mathrm{wt}$ pct in the austenite). An austenite thin-film observed after tempering at $673 \mathrm{~K}\left(400{ }^{\circ} \mathrm{C}\right)$ had approximately 6 at. pet carbon, lower than that

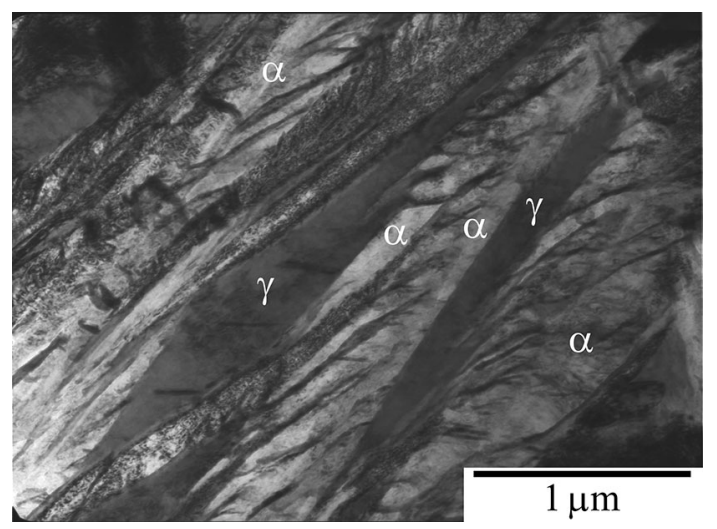

Fig. 2-Alloy A1 completely transformed at $473 \mathrm{~K}\left(200^{\circ} \mathrm{C}\right)$ and tempered at $673 \mathrm{~K}\left(400{ }^{\circ} \mathrm{C}\right)$ for $30 \mathrm{~min}$. Typical microstructure observed by TEM showing bainite plates separated by austenite films. 

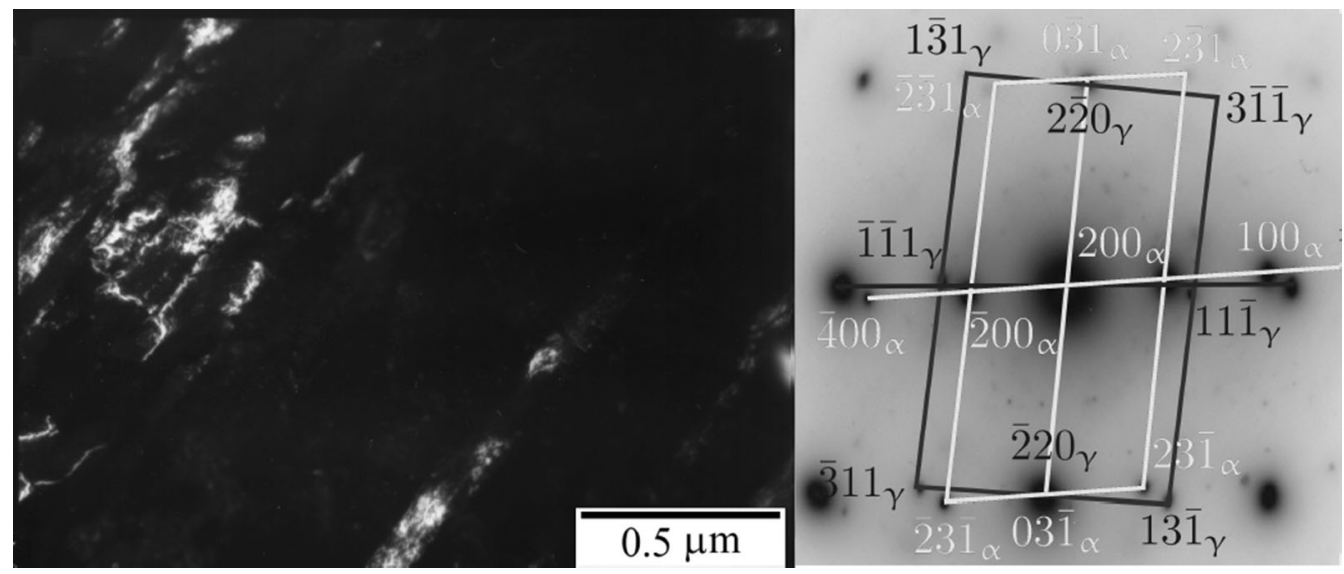

Fig. 3-Dark field image for austenite phase, and corresponding electron diffraction after tempering at $723 \mathrm{~K}\left(450{ }^{\circ} \mathrm{C}\right)$ for $30 \mathrm{~min}$.

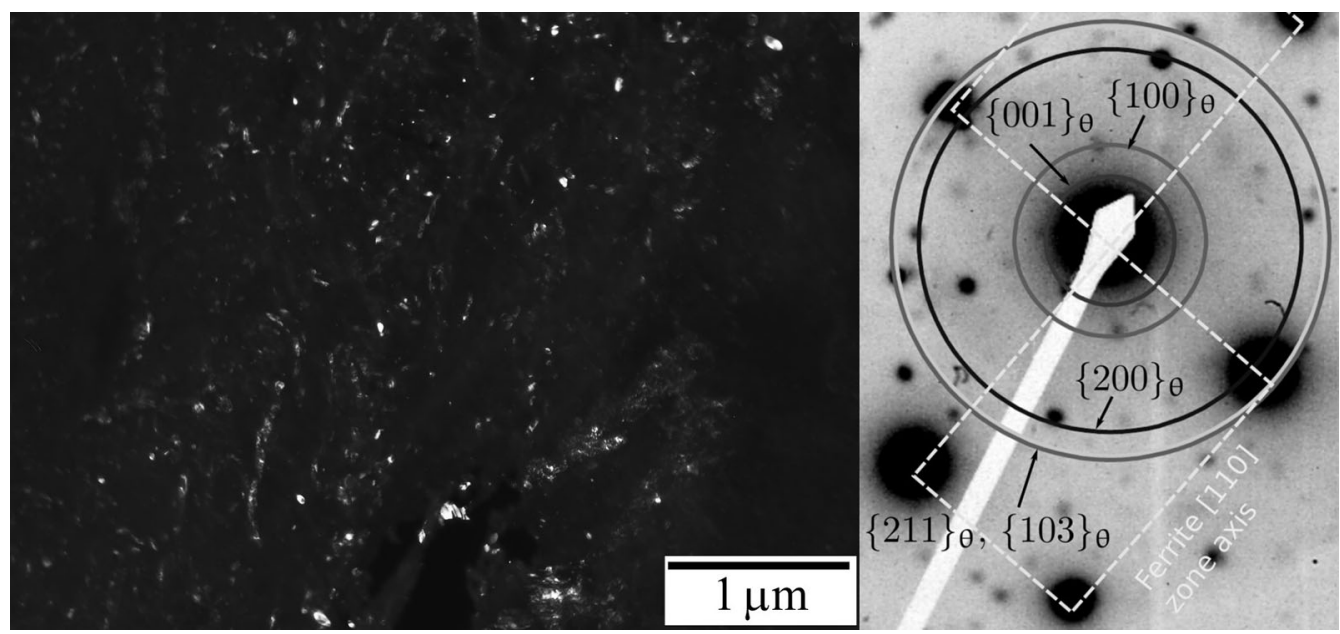

Fig. 4-Electron diffraction after tempering at $773 \mathrm{~K}\left(500^{\circ} \mathrm{C}\right)$ for $30 \mathrm{~min}$. Dark field image for cementite shows nanometer size of carbide particles.

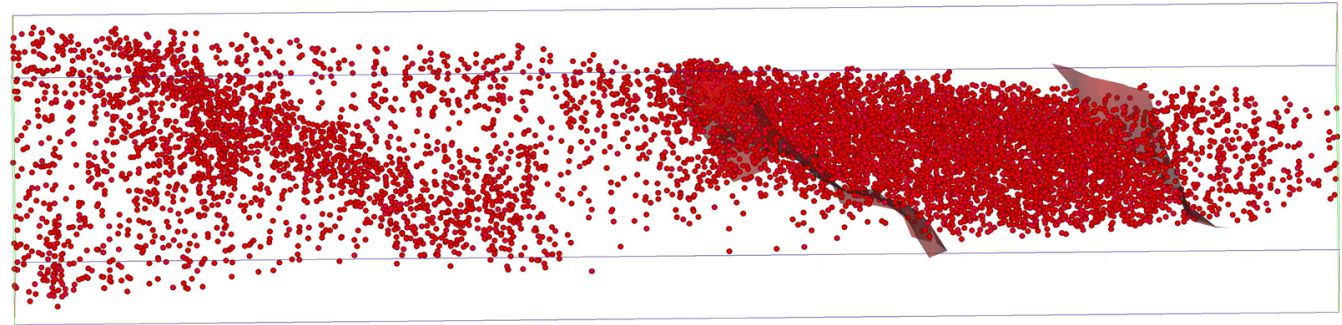

\section{$10 \mathrm{~nm}$}

Fig. 5-Tomographic data acquired for Alloy A1 completely transformed at $473 \mathrm{~K}\left(200{ }^{\circ} \mathrm{C}\right)$ and tempered at $673 \mathrm{~K}\left(400{ }^{\circ} \mathrm{C}\right)$ for $30 \mathrm{~min}$. Volume is approximately $90 \mathrm{~nm} \times 20 \mathrm{~nm} \times 20 \mathrm{~nm}$. Shaded surfaces show position of 2 at. pct carbon isoconcentration surface corresponding to proximity histogram for austenite-ferrite interface (Fig. 6).

observed prior to tempering; however, this may also be explained by correlation between austenite film thickness and degree of supersaturation reported by Caballero et al. ${ }^{[38]}$ From a single observation, it is not possible to discern if the carbon content changed on tempering.
Caballero et al. ${ }^{[30,38,42]}$ have published several papers using atom probe tomography to study tempering in an alloy with higher carbon content, but otherwise similar to that studied here, with composition $\mathrm{Fe}-0.98 \mathrm{C}-1.46 \mathrm{Si}$ $1.89 \mathrm{Mn}-1.26 \mathrm{Cr}-0.26 \mathrm{Mo}-0.09 \mathrm{~V}$ wt pet (Alloy B in Table I). The lower carbon alloy studied here transforms until a 
similar level of carbon is reached in the retained austenite, which means a greater proportion of bainitic ferrite forms on transformation at the same temperature [both $473 \mathrm{~K}$ $\left.\left(200{ }^{\circ} \mathrm{C}\right)\right]$. The transformation of the lower carbon variant results in a slightly thicker bainite plate width $(39 \pm 1 \mathrm{~nm}$ rather than $35 \pm 2 \mathrm{~nm}$ ) and a higher initial hardness due to the larger fraction of bainitic ferrite. Tempering of Alloy B at $673 \mathrm{~K}\left(400{ }^{\circ} \mathrm{C}\right)$ led to three types of 'carbides,' 'lower-bainitic cementite' ( $\sim 25$ at. pct carbon), $\epsilon$-carbide ( $\sim 30$ at. pet carbon), and carbon clusters ( $\sim 14$ at. pct carbon) thought to be associated with lattice defects, perhaps precursors to carbide precipitation. After tempering at $723 \mathrm{~K}\left(450^{\circ} \mathrm{C}\right)$ only $\epsilon$-carbide was observed, and only cementite was observed after tempering at $773 \mathrm{~K}$ $\left(500{ }^{\circ} \mathrm{C}\right) .{ }^{[38]}$

In another volume also tempered at $673 \mathrm{~K}\left(400^{\circ} \mathrm{C}\right)$ for 30 minutes, but analyzed using the LEAP, a carbide particle was observed with a carbon content of
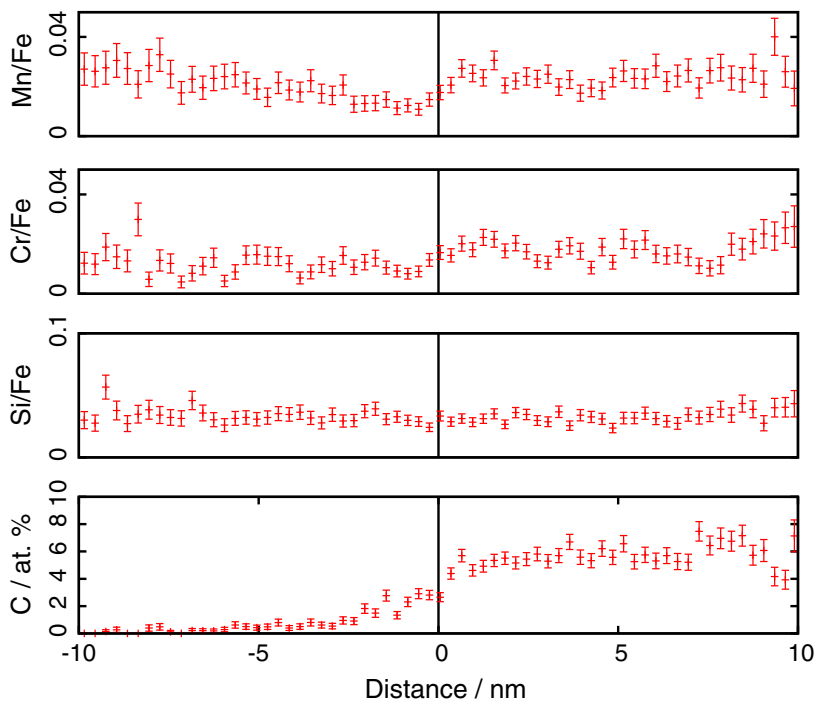

Fig. 6-Austenite-ferrite interface in alloy A1 completely transformed at $473 \mathrm{~K}\left(200{ }^{\circ} \mathrm{C}\right)$ and tempered at $673 \mathrm{~K}\left(400{ }^{\circ} \mathrm{C}\right)$ for $30 \mathrm{~min}$. The proximity histogram for the austenite-ferrite interfaces shown in Fig. 5.
$25 \pm 2$ at. pet with a maximum at $28 \pm 3$ at. pct. Figure 7 shows the carbon atom map with a volume corresponding to $50 \mathrm{~nm} \times 48 \mathrm{~nm} \times 15.5 \mathrm{~nm}$, containing $9.35 \times 10^{-5}$ ions. Figure 8 shows the proximity histogram for the carbide particle at the edge of the volume. The high carbon content was accompanied by increased chromium and manganese, and by lower silicon content. The core of this carbide has almost negligible silicon content and the highest carbon content. In the proximity histogram, the interface has a width of around $3 \mathrm{~nm}$; over this distance, the concentration of each element returns approximately linearly to the matrix content. The true interface may well be sharper, as the width in the proximity histogram also depends on the voxel size $(2 \mathrm{~nm})$ and delocalization (of $4 \mathrm{~nm}$ ). The 25 at. pet $\mathrm{C}$ is equivalent to a metal/carbon ratio of 3.0 , making this particle most likely to be $\mathrm{Fe}_{3} \mathrm{C}$ cementite. The ferrite composition in this second volume averages $0.85 \pm 0.1$ at. pct, lower than that observed in the region associated with the austenite film observed using ECOPOSAP.

The carbon atom map for a sample tempered at $773 \mathrm{~K}\left(500{ }^{\circ} \mathrm{C}\right)$ for 30 minutes is shown in Figure 9, the position of several carbide particles is indicated by use of the 2 at. pct isoconcentration profile. Proximity histograms for the carbides labeled 1 to 5 are shown in Figure 10. The volume of $54 \mathrm{~nm} \times 56 \mathrm{~nm} \times 53 \mathrm{~nm}$ corresponds to acquisition of 3.57 million ions. Previously presented X-ray diffraction results indicate that austenite is no longer present in this condition.

Carbide particles at positions 2, 3, and 4 can be identified as cementite. Having cores of 30 at. pct carbon, they are enriched with both chromium and manganese, and depleted in silicon. The particle at position 4 has a rod shape, approximately $5 \mathrm{~nm}$ across and $20 \mathrm{~nm}$ in length, and possibly has a diffuse 'tail' of lower carbon concentration. Particles at 2 and 3 are ellipsoids with approximate dimension $20 \mathrm{~nm} \times$ $15 \mathrm{~nm} \times 10 \mathrm{~nm}$ both of which are truncated by the edge of the sampling volume. These are similar dimensions to cementite particles observed using the electron microscope in Figure 4.

Table II. Summary of X-ray Diffraction Results Following Tempering Heat Treatments, Alloy A1, Analyzed Using Rietveld Fitting Technique

\begin{tabular}{lcccccc}
\hline$T(\mathrm{~K})$ & $T\left({ }^{\circ} \mathrm{C}\right)$ & $t(\mathrm{~min})$ & $a_{\alpha}(\AA)$ & $W_{\alpha}^{C}(\mathrm{Wt} \mathrm{Pct})$ & $a_{\gamma}(\AA)$ & $W_{\gamma}^{C}(\mathrm{Wt} \mathrm{Pct})$ \\
\hline $473^{*}$ & $200^{*}$ & 0 & $2.876 \pm 0.001$ & $0.27 \pm 0.03$ & $3.624 \pm 0.002$ & $1.28 \pm 0.1$ \\
673 & 400 & 30 & $2.876 \pm 0.002$ & $0.27 \pm 0.06$ & $3.623 \pm 0.002$ & $1.26 \pm 0.06$ \\
673 & 400 & 60 & $2.876 \pm 0.002$ & $0.27 \pm 0.08$ & $3.624 \pm 0.002$ & $1.03 \pm 0.58$ \\
723 & 450 & 30 & $2.876 \pm 0.002$ & $0.29 \pm 0.06$ & $3.612 \pm 0.001$ & $0.90 \pm 0.04$ \\
723 & 450 & 60 & $2.876 \pm 0.002$ & $0.25 \pm 0.08$ & $3.610 \pm 0.003$ & $0.84 \pm 0.09$ \\
773 & 500 & 15 & $2.874 \pm 0.001$ & $0.20 \pm 0.04$ & & $17.5 \pm 1.2$ \\
773 & 500 & 30 & $2.875 \pm 0.002$ & $0.24 \pm 0.05$ & & $8.9 \pm 0.6$ \\
773 & 500 & 60 & $2.875 \pm 0.002$ & $0.21 \pm 0.06$ & & \\
823 & 550 & 30 & $2.875 \pm 0.001$ & $0.22 \pm 0.03$ & & \\
823 & 550 & 60 & $2.873 \pm 0.001$ & $0.18 \pm 0.03$ & & \\
873 & 600 & 30 & $2.873 \pm 0.002$ & $0.17 \pm 0.06$ & & \\
873 & 600 & 60 & $2.872 \pm 0.001$ & $0.15 \pm 0.04$ & & \\
\hline
\end{tabular}

*Transformation temperature rather than tempering temperature, provided for comparison. 
Small spheroidal precipitates at 1 and 5 have approximately 10-15 at. pct carbon; as shown in Figure 10, carbide 5 has a small core of 30 at. pet carbon in similarity to cementite particles. It is possible that these regions are clusters of carbon, or carbide particles too small to be resolved unambiguously, and in the process of either dissolution or growth.

In each case, the silicon content drops to the lowest level at the cores of the carbides, where the carbon, chromium, and manganese are highest; this could not previously be resolved when taking simple profiles through the atom maps of the same data. ${ }^{[13]}$ One possibility is that fluctuation in silicon existed in the matrix phase prior to nucleation, although this is not expected thermodynamically. It seems that this redistribution is due to the high driving force to remove silicon

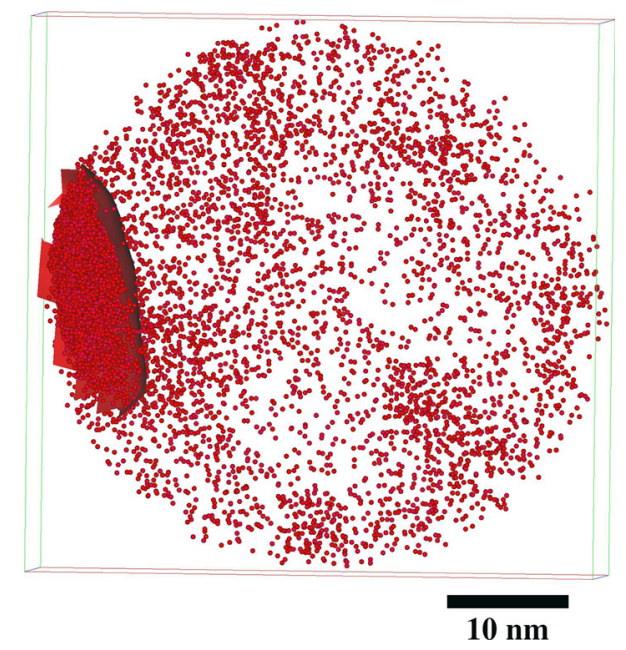

Fig. 7-Atom probe tomography data showing carbon atoms, after tempering for $30 \mathrm{~min}$ at $673 \mathrm{~K}\left(400^{\circ} \mathrm{C}\right)$, volume analyzed is $50 \mathrm{~nm} \times 48 \mathrm{~nm} \times 15.5 \mathrm{~nm}$; iso-surface is for 5 at. pct carbon. Proximity histogram for the carbide is shown in Fig. 8.
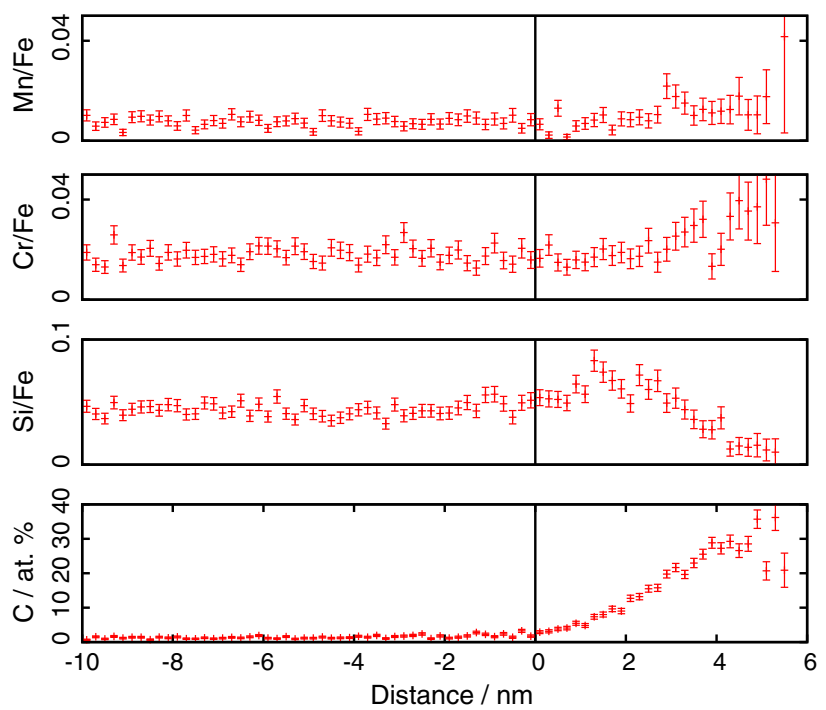

Fig. 8-Proximity histogram for the carbide shown in Fig. 7, heat treatment was $30 \mathrm{~min}$ at $673 \mathrm{~K}\left(400{ }^{\circ} \mathrm{C}\right)$. from cementite. In studies using atom probe tomography, Babu et al. ${ }^{[3]}$ and Thompson and Miller ${ }^{[44]}$ observed cementite precipitation from supersaturated martensite occurred without any initial partitioning of silicon in Fe-0.15C-2Si-3Mn wt pet and Fe- $(0.15,0.4) \mathrm{C}$ $2.2 \mathrm{Cr}-1 \mathrm{Mo}-0.3 \mathrm{Si}-0.5 \mathrm{Mn}$ wt pet, with silicon only being rejected after prolonged annealing. Bhadeshia and Edmonds $^{[45]}$ after Kalish and Cohen ${ }^{[46]}$ also showed that $\epsilon$-carbide is not always a precursor to precipitation of cementite in bainitic steels.

Drawing isoconcentration surfaces for 0.5 at. pct shows many small clusters of carbon in the region of the carbide particles. The 0.5 at. pct value is an arbitrarily chosen value below the average carbon content in the bainitic ferrite of 0.8 at. pct. The volume studied contains a volume of ferrite with relatively few clusters and a volume with a higher density of carbon clusters and carbides, see Figure 11. Given the average carbon contents of the volumes, either the region has decomposed from retained austenite or carbon has diffused into this volume, perhaps as a result of higher defect density or the presence of the carbides.

The average carbon content of the ferrite after tempering at $773 \mathrm{~K} \quad\left(500{ }^{\circ} \mathrm{C}\right)$ was measured as $1.36 \pm 0.1$ and $1.20 \pm 0.1$ at. pct, with maximum $\sim 2.5$ and $\sim 3$ at. pct across composition profiles of the volume shown in Figure 9. ${ }^{[13]}$ The ferrite carbon content is therefore anomalously high compared to the value of $0.85 \pm 0.1$ at. pct observed after tempering at $673 \mathrm{~K}$ $\left(400{ }^{\circ} \mathrm{C}\right)$, possibly a result of the small volumes studied.

In the volumes studied by atom probe tomography, tempering at $673 \mathrm{~K}$ and $773 \mathrm{~K}\left(400{ }^{\circ} \mathrm{C}\right.$ and $\left.500{ }^{\circ} \mathrm{C}\right)$, all the carbide particles were identified as cementite, with the remaining 'particles' being identified as carbon clusters. Of course it needs to be noted that the total volume analyzed by this technique is only a small sample of the microstructure so it is possible that transition carbides could also occur in the bulk sample. Caballero et al. ${ }^{[47]}$ have studied a similar alloy $(\mathrm{B}$, in Table I) with higher carbon and identified that $\epsilon$-carbide and cementite were both present after tempering at $673 \mathrm{~K}\left(400{ }^{\circ} \mathrm{C}\right)$ and $723 \mathrm{~K}\left(450^{\circ} \mathrm{C}\right)$, but only cementite after tempering at $773 \mathrm{~K}\left(500{ }^{\circ} \mathrm{C}\right)$.

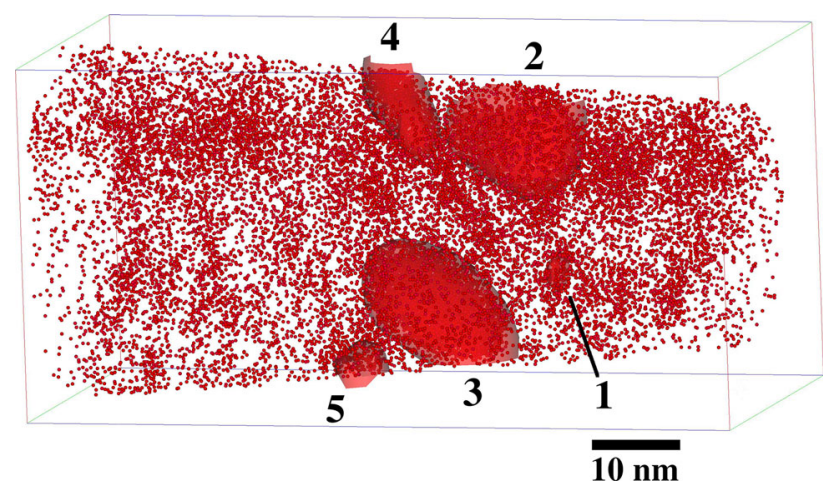

Fig. 9-Volume analyzed after tempering for $30 \mathrm{~min}$ at $773 \mathrm{~K}$ $\left(500{ }^{\circ} \mathrm{C}\right)$, iso-surface is for 2 at. pct carbon. Proximity histograms for carbides labeled 1 and 5 are shown in Fig. 10. 

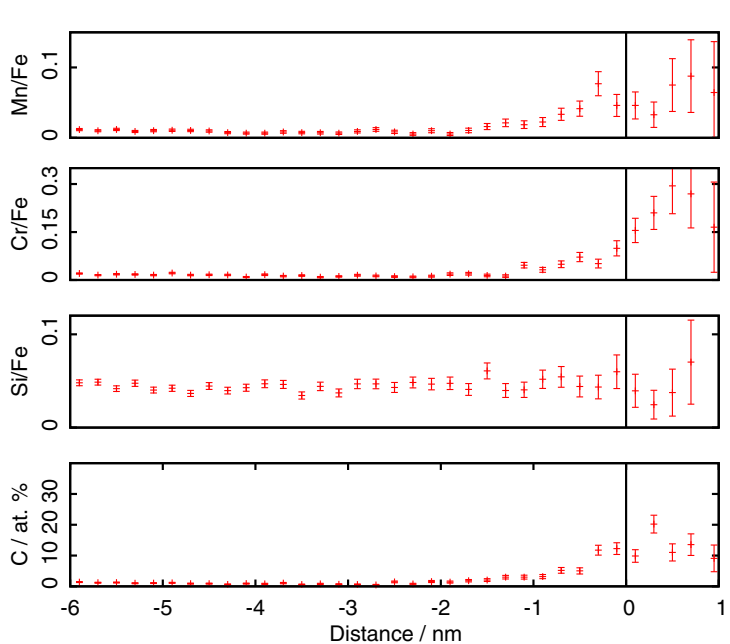

(a)
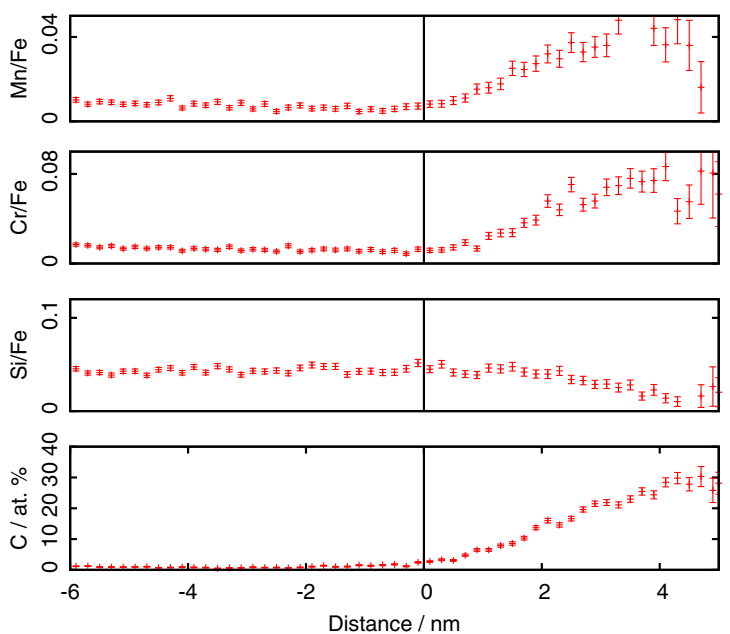

(c)
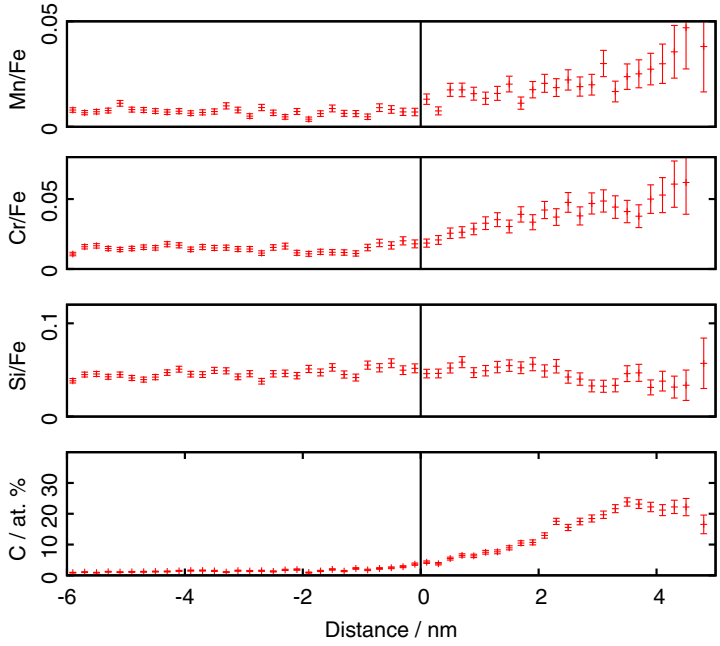

(b)
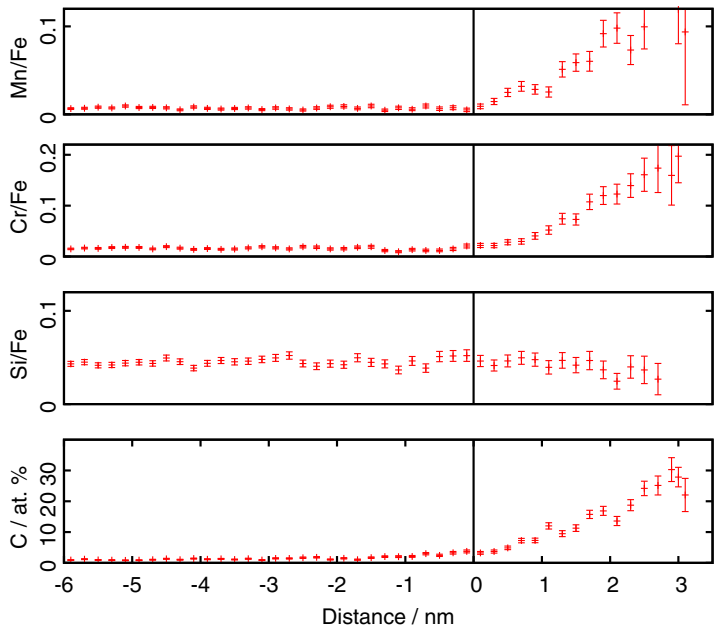

(d)
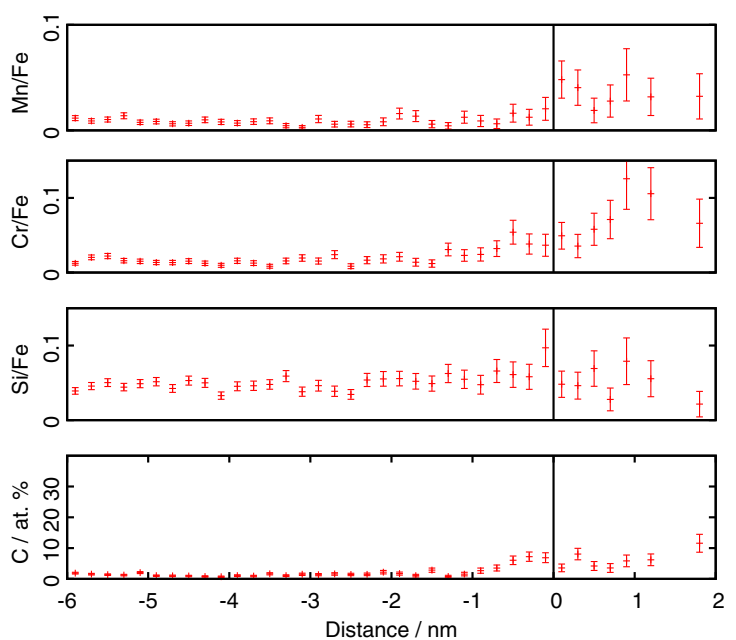

(e)

Fig. 10 - Proximity histograms for a carbide particles observed after tempering for $30 \mathrm{~min}$ at $773 \mathrm{~K}\left(500{ }^{\circ} \mathrm{C}\right)$. $(a)$ to $(e)$ correspond to carbides 1 to 5 labeled in Fig. 9. 


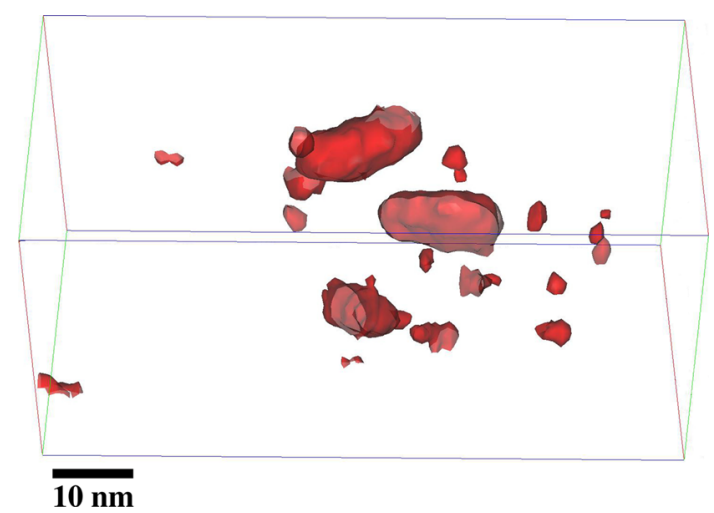

Fig. 11-Volume analyzed after tempering for $30 \mathrm{~min}$ at $773 \mathrm{~K}$ $\left(500{ }^{\circ} \mathrm{C}\right)$, isoconcentration surface is for 0.5 at. pct carbon.

\section{CONCLUSIONS}

Characterization of low-temperature bainite formed by transformation at $473 \mathrm{~K} \quad\left(200{ }^{\circ} \mathrm{C}\right)$ of an alloy Fe-0.75C-1.63Si-1.95Mn-1.48Cr-0.28Mo-0.1V wt pet, and subsequently tempered for 30 minutes at $673 \mathrm{~K}$ and $773 \mathrm{~K}$ $\left(400{ }^{\circ} \mathrm{C}\right.$ and $\left.500{ }^{\circ} \mathrm{C}\right)$ has revealed several features.

Carbon in ferrite decreased from 1.1 to 1 and 0.8 at. pct, respectively after tempering for 30 minutes at $673 \mathrm{~K}$ and $773 \mathrm{~K}\left(400{ }^{\circ} \mathrm{C}\right.$ and $\left.500{ }^{\circ} \mathrm{C}\right)$.

An austenite thin-film observed after tempering at $673 \mathrm{~K}\left(400{ }^{\circ} \mathrm{C}\right)$ had approximately 6 at. pct carbon, and partitioning of manganese at the interface could be observed using the proximity histogram.

Carbide particles were identified after both tempering temperatures, with a core high in carbon and low in silicon. The composition of this low silicon core matches that for cementite based on the metal/carbon ratio and rejection of silicon. The surrounding carbide is not enriched in silicon compared to the ferrite matrix. This is consistent with growth limited by the rate that silicon can be rejected from the core into the matrix.

During tempering, the cementite particles are enriched in chromium and manganese and reject silicon. The tendency for partitioning of solute elements is the same at both temperatures, but the magnitude of composition change is larger at the higher temperature.

The extremely small size of the carbide particles (approximately $5 \mathrm{~nm}$ ) observed after holding at $673 \mathrm{~K}$ $\left(400{ }^{\circ} \mathrm{C}\right)$ and $773 \mathrm{~K}\left(500{ }^{\circ} \mathrm{C}\right)$ for 30 minutes may help to explain the resistance to tempering, a fine distribution of carbides is ideal to prevent grain coarsening.

\section{ACKNOWLEDGMENTS}

The authors are grateful to the Engineering and Physical Sciences Research Council, TATA Steel Europe and The Worshipful Company of Ironmongers for supporting this research. Research supported through a user project supported by ORNL's Center for Nanophase Materials Sciences (CNMS), which is sponsored by the Scientific User Facilities Division, Office of Basic Energy Sciences, U.S. Department of Energy. This manuscript has been authored by UT-Battelle, LLC, under Contract No. DE-AC05-00OR22725 with the U.S. Department of Energy. The United States Government retains and the publisher, by accepting the article for publication, acknowledges that the United States Government retains a non-exclusive, paid-up, irrevocable, world-wide license to publish or reproduce the published form of this manuscript, or allow others to do so, for United States Government purposes.

\section{OPEN ACCESS}

This article is distributed under the terms of the Creative Commons Attribution 4.0 International License (http://creativecommons.org/licenses/by/4.0/), which permits unrestricted use, distribution, and reproduction in any medium, provided you give appropriate credit to the original author(s) and the source, provide a link to the Creative Commons license, and indicate if changes were made.

\section{REFERENCES}

1. F.G. Caballero, H.K.D.H. Bhadeshia, K.J.A. Mawella, D.G. Jones, and P. Brown: Mater. Sci. Technol., 2002, vol. 18, pp. 279-84.

2. F.G. Caballero and H.K.D.H. Bhadeshia: Curr. Opin. Solid State Mater. Sci., 2004, vol. 8, pp. 251-57.

3. H.K.D.H. Bhadeshia: Mater. Sci. Technol., 2005, vol. 21, pp. 1293-1302.

4. H.K.D.H. Bhadeshia: Sci. Technol. Adv. Mater., 2013, vol. 14, p. 014202.

5. H.J. Stone, M.J. Peet, H.K.D.H. Bhadeshia, P.J. Withers, S.S. Babu, and E.D. Specht: Proc. R. Soc. A, 2008, vol. 464, pp. 1009-27.

6. M.J. Peet and H.K.D.H. Bhadeshia: Metall. Mater. Trans. A, 2011, vol. 42A, pp. 3344-48.

7. C. Garcia-Mateo and F.G. Caballero: ISIJ, 2005, vol. 45 (11), pp. $1736-40$

8. H.S. Hasan, M.J. Peet, M.-N. Avettand-Fénoël, and H.K.D.H. Bhadeshia: Mater. Sci. Eng. A, 2014, vol. 589, pp. 340-47.

9. I.B. Timokhina, H. Beladi, X.Y. Xiong, Y.A. Adachi, and P.D. Hodgson: Acta Mater., 2011, vol. 59, pp. 5511-22.

10. H.S. Hasan, M.J. Peet, and H.K.D.H. Bhadeshia: Int. J. Mater. Res., 2012, vol. 103 (11), pp. 1319-24.

11. D. Luo, M. Peet, S.W. Ooi, P. Yan, Z. Yin, and H. Bhadeshia: Mater. Sci. Technol., 2014, vol. 30, pp. 1282-86.

12. C. Garcia-Mateo, M.J. Peet, F.G. Caballero, and H.K.D.H. Bhadeshia: Mater. Sci. Technol., 2004, vol. 20, pp. 814-18.

13. M. J. Peet: Ph.D. thesis, University of Cambridge, 2010.

14. C.N. Hulme-Smith, I. Lonardelli, M.J. Peet, A.C. Dippel, and H.K.D.H. Bhadeshia: Scr. Mater., 2013, vol. 68, p. 195.

15. D.P. Antia, S.G. Fletcher, and M. Cohen: Trans. Am. Soc. Met., 1944, vol. 32, pp. 290-332.

16. K.H. Jack: J. Iron Steel Inst., 1951, vol. 169, pp. 26-36.

17. G.R. Speich and W.C. Leslie: Metall. Trans., 1972, vol. 3, pp. $1043-54$.

18. S.J. Matas and R.F. Hehemann: Trans. Met. Soc. AIME, 1961, vol. 221, pp. 179-85.

19. R.C. Thompson and M.K. Miller: Appl. Surf. Sci., 1996, vol. 46, pp. $2203-13$.

20. M. K. Miller, P. A. Beaven, G. D. W. Smith, S. S. Brenner: Proceedings International Conference of Solid-Solid Phase Transformations, 1981, pp. 863-67.

21. M.K. Miller, P.A. Beaven, and G.D.W. Smith: Metall. Trans., 1981, vol. 12A, pp. 1197-1204. 
22. M.K. Miller, P.A. Beaven, S.S. Brenner, and G.D.W. Smith: Metall. Trans., 1983, vol. 14A, p. 1021.

23. W.S. Owen: Trans. A. S. M., 1954, vol. 46, p. 812.

24. S. J. Barnard, G. D. W. Smith, A. J. Garratt-Reed, J. Vander-Sande: in Advances in the Physical Metallurgy and Applications of Steels, 1982, p. 33

25. L. Chang, G. D. W. Smith: J. Phys. 1984, vol. 45(9), p. 397.

26. E.V. Pereloma, I.B. Timokhina, M.K. Miller, and P.D. Hodgson: Acta Mater., 2007, vol. 55, pp. 2587-98.

27. G. Ghosh and G.B. Olson: Acta Mater., 2002, vol. 50, pp. 2099-2199.

28. H. K. D. H. Bhadeshia, M. Lord, L.-E. Svensson: Proceedings of International Conference: Joining and Welding Solutions to Industrial Problems: JWRI, Osaka University, Suita, 2003, pp. 43-52.

29. E. Kozeschnik and H.K.D.H. Bhadeshia: Mater. Sci. Technol., 2008, vol. 24, pp. 343-47.

30. F.G. Caballero and M.K. Miller: C. G.-M. amd C. Capdevila, S. S. BabuActa Mater., 2008, vol. 56, pp. 188-99.

31. M.J. Peet, S.S. Babu, M.K. Miller, and H.K.D.H. Bhadeshia: Scr. Mater., 2004, vol. 50, pp. 1277-81.

32. D.J. Dyson and B. Holmes: J. Iron Steel Inst., 1970, vol. 208, p. 469.

33. M. J. Peet: LP2C: http://mathewpeet.org/thesis/programs/, 2009.

34. M.K. Miller, A. Cerezo, H.G. Hetherington, and G.D.W. Smith: Atom Probe Field Ion Microscopy, Clarendon Press, Oxford, 1996.

35. O.C. Hellman, J.A. Vandenbroucke, J. Rüsing, D. Isheim, and D.N. Seidman: Microsc. Microanal., 2000, vol. 6 (5), pp. 437-44.
36. O.C. Hellman and D.N. Seidman: Mater. Sci. Eng. A, 2002, vol. A327, pp. 24-28.

37. O.C. Hellman, J.B. du Rivage, and D.N. Seidman: Ultramicroscopy, 2000, vol. 84 (213e), p. 24

38. F.G. Caballero, M.K. Miller, A.J. Clarke, and C. Garcia-Mateo: Scr. Mater., 2010, vol. 63, pp. 442-45.

39. J.H. Jang, H.K.D.H. Bhadeshia, and D.W. Suh: Scr. Mater., 2013, vol. 68, pp. $195-98$

40. C.N. Hulme-Smith, I. Lonardelli, A.C. Dippel, and H.K.D.H. Bhadeshia: Scr. Mater., 2013, vol. 69 (5), pp. 409-12.

41. C.N. Hulme-Smith, M.J. Peet, I. Lonardelli, A.C. Dippel, and H.K.D.H. Bhadeshia: Mater. Sci. Technol., 2015, vol. 31 (2), pp. 254-56.

42. F.G. Caballero, M.K. Miller, and C. Garcia-Mateo: Metall. Mater. Trans. A, 2011, vol. 42A, pp. 3660-68.

43. S.S. Babu, K. Hono, and T. Sakurai: Metall. Trans., 1994, vol. 25A, pp. 499-508.

44. R.C. Thompson and M.K. Miller: Acta Mater., 1998, vol. 46, pp. 2203-13.

45. H.K.D.H. Bhadeshia and D.V. Edmonds: Met. Sci., 1979, vol. 13, pp. 325-34.

46. D. Kalish and M. Cohen: Mater. Sci. Eng., 1970, vol. 6, pp. 156-66.

47. F.G. Caballero, M.K. Miller, S.S. Babu, and C. Garcia-Mateo: Acta Mater., 2007, vol. 55, pp. 381-90.

48. C. Garcia-Mateo, F.G. Caballero, and H.K.D.H. Bhadeshia: J. Phys., 2003, vol. 112, pp. 17-25.

49. C. Garcia-Mateo, F.G. Caballero, and H.K.D.H. Bhadeshia: ISIJ Int., 2003, vol. 43 (8), pp. 1238-43. 